\title{
Reference genes for livestock gene expression profiling - Literature review
}

\author{
Ádám Simon - Zsuzsa Zakarné Aszalós - András Jávor - Levente Czeglédi \\ University of Debrecen Faculty of Agricultural and Food Sciences and Environmental Management, \\ Institute of Animal Science, Biotechnology and Nature Conservation, Debrecen \\ simon.a@agr.unideb.hu
}

\begin{abstract}
SUMMARY
Quantitative real-time polymerase chain reaction $(q P C R)$ is an essential tool for understanding animal cell's response to developmental progression or to different experimental conditions at gene expression level. However the reliability of this method heavily lies on proper normalization (measuring a target and a reference gene's expression from the same sample to correct for technical related variations).

Our literature review aimed to summarize the articles addressing the most important livestock species in regards of reference gene stability used as normalizers for quantitative real-time polymerase chain reaction experiments. Stably expressing reference genes were categorized into 14 distinct groups according to gene function. The number of reference genes tested and the publication numbers according to years and the ranking algorithms were also noted.

Counting showed that genes encoding ribosomal protein components are ranked as most stable in majority of cases and therefore should be taking into account for qPCR stable normalizer gene finding experiments.
\end{abstract}

Keywords: gene expression, normalization, quantitative real-time polymerase chain reaction

\section{ÖSSZEFOGLALÁS}

A kvantitativ valós-idejü polimeráz láncreakció (qPCR) elengedhetetlen eszköze a génexpressziós kísérleteknek, ezekkel közelebb kerülhetünk a gének, az állat fejlödése, vagy bizonyos kísérleti körülményekre adott válaszának megértésében. A módszer megbizhatósága nagyban függ azonban a megfelelö normalizációtól (a célgénünk és egy ún. referencia gén expressziójának mérése egyazon mintából, a technikai variációk minimalizálása érdekében).

Az irodalmi összefoglalónk célja volt összegezni azokat a publikációkat, melyek a legfontosabb haszonállatokkal végzett kisérletekben stabil referencia gén keresésre irányultak. A stabilan kifejezödö géneket 14 eltérö kategóriába soroltuk azok funkciója alapján. A referencia gének stabilitásával foglalkozó cikkek számát az publikálás éveinek függvényében, a rangsoroló algoritmusokat, valamint a tesztelt referencia gének számát az egyes publikációkban szintén megvizsgáltuk.

Eredményeink alapján a fehérjeszintézisben szerepet játszó riboszóma alegységeket kódoló gének nagyobb arányban rangsorolódnak stabilnak a többi kategóriával szemben ezért ajánlott lehet minden esetben stabilitás vizsgálatuk a qPCR elökísérletekben.

Kulcsszavak: gén expresszió, normalizáció, kvantitativ valós-idejü polimeráz láncreakció

\section{INTRODUCTION}

Quantitative real-time polymerase chain reaction (qPCR) is an essential tool for understanding animal cell's response to developmental progression or to different experimental conditions at gene expression level. Relevant gene expressional changes are often small and can be hindered by technically related variations. These variations arise from unequal starting sample amounts, dissimilar RNA isolation efficiencies, inaccurate RNA concentration measurement before reverse transcription, etc. Therefore results obtained by this method heavily relies on proper normalization. The most common technique correcting for technically related variations is the use of reference genes (Pfaffl 2001).

Reference genes (or formally called housekeeping genes) are genes which encodes gene products essential for every cells basic cellular functions like metabolism (carbohydrate, lipid and so on), transcription, translation, protein folding, signal transduction etc. This assumes that, these genes shows stable and constant level unregulated by experimental effects to maintain these important functions. The popular equation for gene expression ratio determination which takes into account the normalisation with reference genes is published by
Pfaffl (2001). Applicability of them can only be useful if their expression is not affected by the experimental condition itself. Therefore in the last decade several algorithms were developed to test reference gene stability and an emerging number of articles published which test them under different experimental conditions.

Beside human and laboratory animals publications related to farm animals started to address reference gene stability in the last decade as well. Chapman and Waldenström (2015) analysed the literature to see which are the most commonly used reference genes in vertebrate gene expression studies and found that $A C T B$ (used in $38 \%$ of studies) encoding beta-actin a cytoskeletal structure protein and GAPDH $(37 \%)$ glyceraldehyde 3-phosphate dehydrogenase takes part in glycolysis with $R N 18 S(12 \%)$ encoding $18 \mathrm{~S}$ ribosomal RNA and their results showed that only 15 percent of total publications tested a panel of potential reference genes for stability before used as normalizer. However the aforementioned genes are the most commonly used ones, this does not mean that these are always stable under all conditions. Bionaz and Loor (2007) found that $A C T B$ and $G A P D H$ are the less stably reference genes when investigated in cattle mammary gland. While Bougarn et al. (2011) found that $A C T B$ is the 
most stable expressing reference gene in cattle mammary epithelial cells unstimulated and stimulated with mastitis pathogens. Similarly RN18S ranked better as other candidates in chicken lung cells infected with influenza virus (Kuchipudi et al. 2012), but ranked poor in similar tissue when infected with avian infectious bronchitis virus (Fan et al. 2012). These examples shows the importance of stability testing. Testing algorithms freely available by Andersen et al. (2004), Chervoneva et al. (2010), Pfaffl et al. (2004), Silver et al. (2006) and Vandesompele et al. (2002).

Our literature review aimed to summarize the articles addressing the most important livestock species in regards of reference gene stability used as normalizers for quantitative real-time polymerase chain reaction experiments. Stably expressing reference genes were categorized into distinct groups and investigated if one of the category is ranked better over others across all the various experimental situations.

\section{MATERIALS AND METHODS}

A literature review was performed using Web of Science v5.23.2 bibliographic database (available at https://webofknowledge.com/) with keywords for TOPIC "cattle or chick* or goat or horse or pig or rabbit or sheep AND reference gene" and obtained a total of 118 publications. Experimental condition(s), the investigated tissue type(s) the most stable and the least stable two reference genes were collected and shown in Table 1 as a representative table including chicken related experiments and a summary in Table 2 for the rest of the aforementioned species. The type and the number of applied methods were also noted and counted. When the authors did not calculate the final ranks for each gene, we did it with geometric averaging of the different available rankings and finally rank them as the geometric mean with smallest value being most stable (as recommended by Chen et al. 2011). Gene products were classified using the European Bioinformatics Institute protein database (can be found at http://www. ebi.ac.uk/). One-way analysis of variance (ANOVA) and Tukey post hoc test were applied to compare the means of reference genes tested in each year using GraphPad Prism 6 (La Jolla, California, USA). Classification was the following: cat I.: cytoskeletal components, cat II.: signal transduction, cat III.: transcription, cat IV.: protein degradation, cat $\mathrm{V}$.: mitochondrial electron transport chain, cat VI.: ribosomal protein component, cat VII.: ribosomal RNA, cat VIII.: protein folding, cat IX.: carbohydrate metabolism, cat X.: nucleotide metabolism, cat XI.: protein transport, cat XII.: chromosome organization, cat XIII.: heme biosynthesis.

Example table representing publications addressing Gallus gallus related experiments

\begin{tabular}{|c|c|c|c|c|c|c|}
\hline Samples & $\begin{array}{c}\text { Experimental } \\
\text { conditions }\end{array}$ & $\begin{array}{l}\text { Genes with the } \\
\text { most stable expression }\end{array}$ & $\begin{array}{c}\text { Genes with the } \\
\text { least stable expression }\end{array}$ & $\begin{array}{c}\text { Genes } \\
\text { used }\end{array}$ & $\begin{array}{c}\text { Algorithms } \\
\text { used }\end{array}$ & Reference \\
\hline Four tissues & $\begin{array}{l}\text { Cross-tissue } \\
\text { examination }\end{array}$ & $\begin{array}{c}R P L 32(\mathrm{VI})^{*} \\
B 2 M(\mathrm{X}) \\
S D H A(\mathrm{~V})\end{array}$ & $\begin{array}{c}T B P(\mathrm{III}) \\
Y W H A Z(\mathrm{II})\end{array}$ & 5 & $\begin{array}{c}\text { BestKeeper, } \\
\text { Comparative } \Delta \mathrm{Cq} \text {, } \\
\text { geNorm, } \\
\text { NormFinder } \\
\end{array}$ & $\begin{array}{l}\text { Bagés } \\
\text { et al. } \\
(2015)\end{array}$ \\
\hline Lymphoid organs & $\begin{array}{l}\text { Cross-tissue } \\
\text { examination }\end{array}$ & $\begin{array}{c}T B P(\mathrm{III}) \\
G A P D H(\mathrm{IX}) \\
R N 28 S(\mathrm{VII})\end{array}$ & $\begin{array}{l}B 2 M(\mathrm{X}) \\
G U S B(\mathrm{o}) \\
T U B A T(\mathrm{I}) \\
\end{array}$ & 7 & $\begin{array}{l}\text { BestKeeper, } \\
\text { geNorm, } \\
\text { NormFinder } \\
\end{array}$ & $\begin{array}{c}\text { Borowska } \\
\text { et al. } \\
(2016)\end{array}$ \\
\hline Blood & $\begin{array}{l}\text { Lipopolysaccharide } \\
\text { administration }\end{array}$ & $\begin{array}{c}U B(\mathrm{IV}) \\
G 6 P D H(\mathrm{IX})\end{array}$ & $\begin{array}{c}A C T B(\mathrm{I}) \\
H P R T(\mathrm{XI}) \\
G A P D H(\mathrm{IX})\end{array}$ & 5 & $\begin{array}{l}\text { BestKeeper, } \\
\text { geNorm }\end{array}$ & $\begin{array}{c}\text { De Boeve } \\
\text { et al. } \\
(2008)\end{array}$ \\
\hline Nine different tissue & $\begin{array}{c}\text { Control and infected } \\
\text { with avian infectious } \\
\text { bronchitis virus }\end{array}$ & $\begin{array}{c}U B(\mathrm{IV}) \\
G A P D H(\mathrm{IX})\end{array}$ & $\begin{array}{c}A C T B(\mathrm{I}) \\
G 6 P D H(\mathrm{IX}) \\
R N 18 S(\mathrm{VII}) \\
\end{array}$ & 5 & geNorm & $\begin{array}{c}\text { Fan } \\
\text { et al. } \\
(2012)\end{array}$ \\
\hline Lung-derived cells & $\begin{array}{l}\text { Influenza virus } \\
\text { infection }\end{array}$ & $\begin{array}{l}R N 18 S \text { (VII) } \\
G A P D H \text { (IX) }\end{array}$ & $A C T B(\mathrm{I})$ & 3 & $\begin{array}{l}\text { BestKeeper, } \\
\text { NormFinder }\end{array}$ & $\begin{array}{c}\text { Kuchipudi } \\
\text { et al. } \\
(2012) \\
\end{array}$ \\
\hline Pectoralis major & $\begin{array}{l}\text { Four levels of lysine } \\
\text { supplementation }\end{array}$ & $\begin{array}{c}H M B S(\mathrm{XIV}) \\
A C T A 1(\mathrm{I}) \\
H P R T(\mathrm{XI})\end{array}$ & $\begin{array}{l}U B C(\mathrm{IV}) \\
B 2 M(\mathrm{X}) \\
T F R C(\mathrm{II})\end{array}$ & 13 & $\begin{array}{c}\text { BestKeeper, } \\
\text { Comparative } \Delta \mathrm{Cq} \text {, } \\
\text { geNorm Excel, } \\
\text { geNorm SAS, } \\
\text { NormFinder }\end{array}$ & $\begin{array}{l}\text { Nascimento } \\
\text { et al. } \\
(2015)\end{array}$ \\
\hline Embryo fibroblasts & $\begin{array}{c}\text { Avian leucosis virus } \\
\text { infection }\end{array}$ & $\begin{array}{c}R P L 30(\mathrm{VI}) \\
S D H A(\mathrm{~V}) \\
H P R T(\mathrm{XI}) \\
\end{array}$ & $\begin{array}{l}B 2 M(\mathrm{X}) \\
A C T B(\mathrm{I} \\
T U B B(\mathrm{I}) \\
\end{array}$ & 11 & geNorm & $\begin{array}{l}\text { Yang } \\
\text { et al. } \\
(2013) \\
\end{array}$ \\
\hline Embryo fibroblasts & $\begin{array}{l}\text { H5N1 infected and } \\
\text { control }\end{array}$ & $\begin{array}{c}Y W H A Z(\mathrm{II}) \\
R P L 4(\mathrm{VI}) \\
A C T B(\mathrm{I})\end{array}$ & $\begin{array}{c}A L B(\mathrm{I}) \\
R P L 30(\mathrm{VI}) \\
T U B B(\mathrm{I})\end{array}$ & 11 & geNorm & $\begin{array}{l}\text { Yue } \\
\text { et al. } \\
(2010)\end{array}$ \\
\hline
\end{tabular}

Note: *roman numbers in parentheses represents a category number described in materials and methods, o means other 
Summary table representing genes ranked as the most commonly stable or most commonly unstable in the further examined species

\begin{tabular}{|c|c|c|c|}
\hline Species & $\begin{array}{l}\text { Gene with the most } \\
\text { stable expression }\end{array}$ & $\begin{array}{c}\text { Genes with the least } \\
\text { stable expression }\end{array}$ & References \\
\hline $\begin{array}{l}\text { cattle } \\
\text { (Bos } \\
\text { taurus) }\end{array}$ & $\begin{array}{l}\text { RPS9 }(\mathrm{VI})^{*},(n=4) \\
Y W H A Z(\mathrm{II}),(n=4)\end{array}$ & $A C T B(\mathrm{I}),(n=6)$ & $\begin{array}{l}\text { Anstaett et al. (2010), Baddela et al. (2014), Bionaz and Loor (2007), } \\
\text { Bonnet et al. (2013), Bougarn et al. (2011), Brym et al. (2013), } \\
\text { De Ketelaere et al. (2006), Emam et al. (2015), Fredericksen et al. (2015), } \\
\text { Goossens et al. (2005), Hosseini et al. (2009), } \\
\text { Janovick-Guretzky et al. (2007), Kadegowda et al. (2009), } \\
\text { Khan et al. (2014), Lecchi et al. (2012), Lisowsk et al. (2008), } \\
\text { Liu et al. (2015), Luchsinger et al. (2012), Macabelli et al. (2014), } \\
\text { Mihi et al. (2011), Ontsouka et al. (2004), Ostrowska et al. (2014), } \\
\text { Pérez et al. (2008), Rekawiecki et al. (2012), Rekawiecki et al. (2013), } \\
\text { Robinson, et al. (2007), Ross et al. (2010), Saremi et al. (2012), } \\
\text { Schoen et al. (2014), Spalenza et al. (2011), Verbeke et al. (2015), } \\
\text { Walker et al. (2009), Zhao et al. (2016) }\end{array}$ \\
\hline $\begin{array}{l}\text { goat } \\
\text { (Capra } \\
\text { hircus) }\end{array}$ & $Y W H A Z(\mathrm{II}),(n=3)$ & $R N 18 S$ (VII), $(n=3)$ & $\begin{array}{l}\text { Bai et al. (2014), Bonnet et al. (2013), Finot et al. (2011), } \\
\text { Frota et al. (2009), Jarczak et al. (2014), Manjunath et al. (2015), } \\
\text { Modesto et al. (2013), Najafpanah et al. (2013), } \\
\text { Zhang et al. (2013), Zhu et al. (2015) }\end{array}$ \\
\hline $\begin{array}{l}\text { horse } \\
\text { (Equus } \\
\text { caballus) }\end{array}$ & $U B B(\mathrm{IV}),(n=3)$ & $\begin{array}{c}A C T B(\mathrm{I}),(n=3) \\
G A P D H(\mathrm{IX}),(n=3)\end{array}$ & $\begin{array}{l}\text { Ahn et al. (2010), Beekman et al. (2011), Bogaert et al. (2006), } \\
\text { Bruynsteen et al. (2013), Cappelli et al. (2008), } \\
\text { Cieslak et al. (2015), Hjertner et al. (2013), Kayis et al. (2011), } \\
\text { Klein et al. (2011), Looijen et al. (2016), Paris et al. (2011), } \\
\text { Smits et al. (2009), Zhang et al. (2009) }\end{array}$ \\
\hline $\begin{array}{l}\text { pig } \\
\text { (Sus } \\
\text { scrofa) }\end{array}$ & $R P L 4(\mathrm{VI}),(n=4)$ & $A C T B(\mathrm{I}),(n=5)$ & $\begin{array}{l}\text { Chooi et al. (2013), Cinar et al. (2012), Erkens et al. (2006), } \\
\text { Facci et al. (2011), Feng et al. (2010), Gu et al. (2011), } \\
\text { Huang et al. (2016), Kuijk et al. (2007), Lee et al. (2015), Li et al. (2011), } \\
\text { Li et al. (2016), Manjarin et al. (2011), Martínez-Giner et al. (2013), } \\
\text { Martino et al. (2011), McBryan et al. (2010), McCulloch et al. (2012), } \\
\text { Monaco et al. (2010), Muráni et al. (2007), Nesvadbová et al. (2011), } \\
\text { Nygard et al. (2007), Park et al. (2015), Pierzchała et al. (2011), } \\
\text { Piórkowska et al. (2011), Ropka-Molik et al. (2012), } \\
\text { Skovgaard et al. (2007), Svobodová et al. (2008), Tramontana et al. (2008), } \\
\text { Uddin et al. (2011), Wang et al. (2014), Wang et al. (2015), } \\
\text { Xiang-Hong et al. (2011), Zhang et al. (2012) }\end{array}$ \\
\hline $\begin{array}{l}\text { rabbit } \\
\text { (Oryctolagus } \\
\text { cuniculus) }\end{array}$ & $Y W H A Z(\mathrm{II}),(n=3)$ & $B 2 M(\mathrm{X}),(n=2)$ & $\begin{array}{l}\text { Llobat et al. (2011), Ma et al. (2015), Mamo et al. (2008), } \\
\text { Nachar et al. (2014), Peng et al. (2012) }\end{array}$ \\
\hline $\begin{array}{l}\text { sheep } \\
\text { (Ovis } \\
\text { aries) }\end{array}$ & $G A P D H(\mathrm{IX}),(n=3)$ & $\begin{array}{c}A C T B(\mathrm{I}),(n=5) \\
Y W H A Z(\mathrm{II}),(n=5)\end{array}$ & $\begin{array}{l}\text { Budhia et al. (2006), Garcia-Crespo et al. (2005), Jiang et al. (2015), } \\
\text { Lyahyai et al. (2009), Mahakapuge et al. (2016), O’Connor et al. (2013), } \\
\text { Passmore et al. (2009), Paten et al. (2014), Peletto et al. (2011), } \\
\text { Pereira-Fantini et al. (2016), Puech et al. (2015), } \\
\text { Serrano et al. (2011), Vorachek et al. (2013), Xu et al. (2015), } \\
\text { Zang et al. (2011), Zaros et al. (2010) }\end{array}$ \\
\hline
\end{tabular}

Note: *roman numbers in parentheses represents a category number described in materials and methods, o means other, $\mathrm{n}$ summarize the events when the given gene ranked as stable or unstable

\section{RESULTS AND DISCUSSION}

We processed 118 publications overall including the following species: cattle (33), chicken (8), goat (10), horse (13), pig (32), rabbit (5) and sheep (16). No differences were found in the number of reference genes tested depending on publication date, but an increasing number of publications started to address reference gene stability after 2008 in livestock species (Figure 1), which can be a result of increased awareness for proper normalization due to a publication contains important guidelines which was published at 2009 (Bustin et al. 2009).
When we counted how many methods were used we found that most often a single method was applied in $44.44 \%$ of the cases, two in $25.64 \%$, three $20.51 \%$, four $6.84 \%$, and $2.56 \%$ used five algorithm to test reference gene stability. In majority of cases the method called geNorm (Vandesompele et al. 2002) were used in $47.08 \%$ of the cases followed by NormFinder (Andersen et al. 2004) 28.75\% BestKeeper (Pfaffl et al. 2004) $16.25 \%$ the comparative $\Delta$ Cq method (Silver et al. 2006) $4.58 \%$, others like descriptive statistic and principal component analysis in $3.33 \%$. of papers The aforementioned most common algorithms use either descriptive statistics or multivariate analysis of variance. 
Figure 1: Mean number of reference genes tested in livestock animal related publications (left) and number of publications regarding the topic in the last 13 year (right)
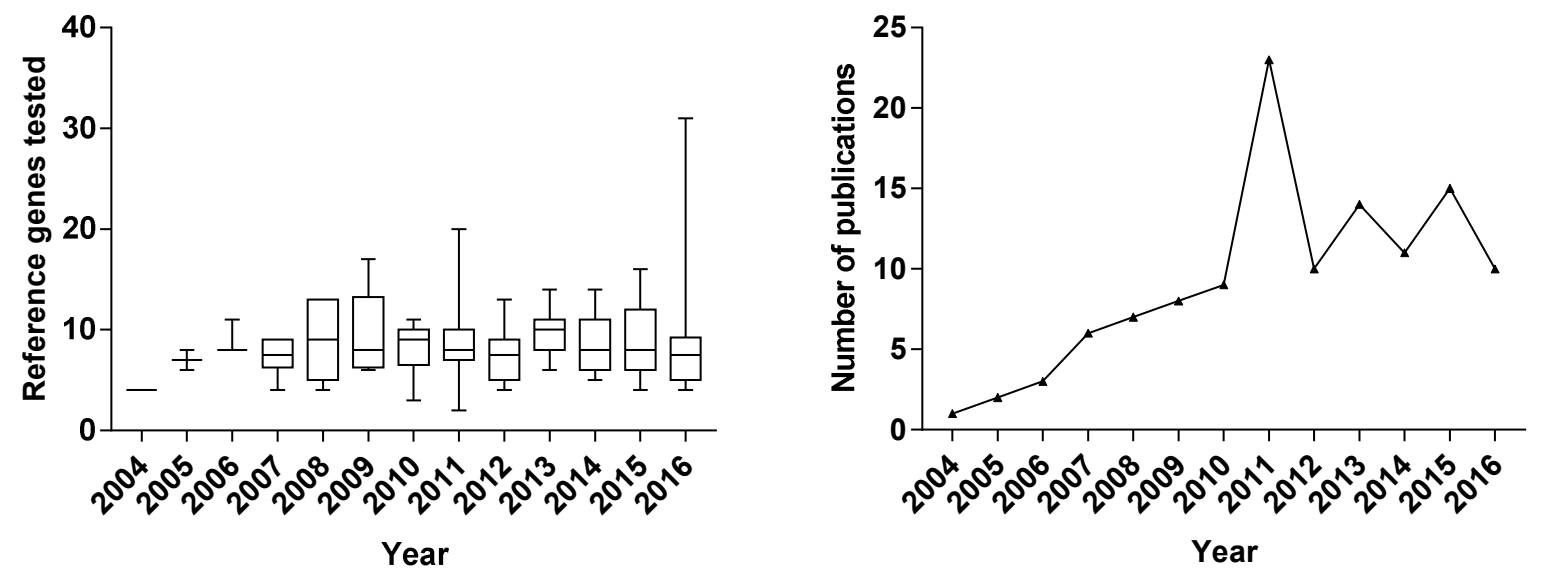

Note: boxes represent the interquartile interval (25-75\%) with median value; whiskers represent minimum and maximum values. ANOVA multiple comparisons test showed no significant differences at $\alpha=5 \%$, P resulted as $>0.9598$ after each comparison. *due to lack of adequate number of cases only one value is showed for 2004.

Currently there is no scientifically consensus which method provides the best results, but geometric averaging of the rankings derived from each method, followed by re-ranking can increase robustness (Kozera and Rapacz 2013).

The most commonly used method amongst all for reference gene stability testing is geNorm. This method first calculate the pairwise variation for each reference gene with all other reference genes is calculated as the standard deviation of the logarithmic transformed expression ratios. This followed by the calculation of a reference gene stability value ( $\mathrm{M}$ value) which is the average pairwise variation of a single reference gene. The lower of this value, the more stably expressed is a reference gene. All of the popular methods can easily be conducted on Microsoft Excel. Popularity of geNorm may be due to this was the first reference gene selector algorithm published as early as 2002 .

Results showed that publications addressing reference gene stability in livestock appeared as early as 2004 two year after the release of geNorm (Vandesompele et al. 2002) and continued to grow in number in the next years. Classifying the reference genes into distinct classes resulted that ribosomal protein encoding genes (Figure 2) ranked better over other categories. Inversely counting was also done with the least stable ones which resulted as genes encoding glycolytic enzymes counted 52 times $(17.82 \%)$ as most unstable expressed genes.

Thorrez et al. (2008) meta-analysed some publicly available microarray datasets derived from 22 different tissues. Ribosomal protein encoding genes are most stably expressed amongst of all the investigated genes but found that they exhibit important tissue dependent variation in mRNA expression and therefore they cannot be considered as universal reference genes. Similarly according to our review we found that reference genes encoding ribosomal proteins ranked most frequently as stable, otherwise counting was also done with the least stable ones and resulted as ribosomal encoding genes are also the fourth most unstable gene category in some instances (35 case, 12.03\%), this observation also confirms that genes in this category are cannot be considered as universal reference genes.

Figure 2: Proportion of different functional categories as
stable reference genes

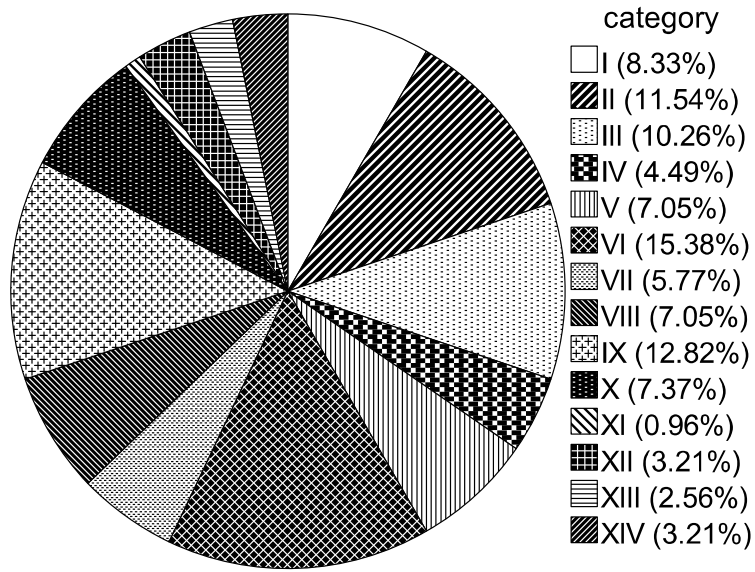

Note: category 6 (ribosomal proteins encoding genes) with $15.38 \%$ represents the highest percentage over other categories. Total gene count was $n=313$. Classification was the following: cat I.: cytoskeletal components, cat II.: signal transduction, cat III.: transcription, cat IV.: protein degradation, cat V.: mitochondrial electron transport chain, cat VI.: ribosomal protein component, cat VII.: ribosomal RNA, cat VIII.: protein folding, cat IX.: carbohydrate metabolism, cat X.: nucleotide metabolism, cat XI.: protein transport, cat XII.: chromosome organization, cat XIII.: heme biosynthesis, XIV.: other.

\section{CONCLUSION}

Literature review of publications investigating reference gene stability in livestock species revealed the gene types which are most often ranked as stable in qPCR experiments. The highest percentage represents genes that encode ribosomal proteins. We recommend 
that genes encoding ribosomal components should be included for pilot experiments aiming to identify stable reference genes under the particular experimental conditions. This should be done prior in order to reliable quantify the target gene's expression.

\section{ACKNOWLEDGEMENTS}

This work was supported by New Széchenyi Plan of Hungary, co-financed by the European Social Fund (TÁMOP-4.2.2.D-15/1/KONV-2015-0016); TÁMOP 4.2.4.A/2-11-1-2012-0001, Ministry of National Development, Hungary (AGR-PIAC-13-1-2013-0008), University of Debrecen, Hungary (RH/885/2013).

\section{IRODALOM}

Ahn, K.-Bae, J.-Nam, K.-Lee, C.-Park, K.-Lee, H.-Cho, B.-Kim, H. (2010): Identification of reference genes for normalization of gene expression in thoroughbred and Jeju native horse (Jeju pony) tissues. Genes \& Genomics. 3. 33: 245-250.

Andersen, C. L.-Jensen, J. L.-Ørntoft, T. F. (2004): Normalization of real-time quantitative reverse transcription-PCR data: A model-based variance estimation approach to identify genes suited for normalization, applied to bladder and colon cancer data sets. Cancer Research. 64: 5245-5250.

Anstaett, O. L.-Brownlie, J.-Collins, M. E.-Thomas, C. J. (2010): Validation of endogenous reference genes for RT-qPCR normalisation in bovine lymphoid cells (BL-3) infected with Bovine Viral Diarrhoea Virus (BVDV). Veterinary Immunology and Immunopathology. 3-4. 137: 201-207.

Baddela, V. S.-Baufeld, A.-Yenuganti, V. R.-Vanselow, J.-Singh, D. (2014): Suitable housekeeping genes for normalization of transcript abundance analysis by real-time RT-PCR in cultured bovine granulosa cells during hypoxia and differential cell plating density. Reproductive Biology and Endocrinology RB\&E. 12: 118-118.

Bagés, S.-Estany, J.-Tor, M.-Pena, R. (2015): Investigating reference genes for quantitative real-time PCR analysis across four chicken tissues. Gene. 561: 82-87.

Bai, W. L.-Yin, R. H.-Yin, R. L.-Jiang, W. Q.-Wang, J. J.-Wang, Z Y.-Zhu, Y. B.-Zhao, Z. H.-Yang, R. J.-Luo, G. B.-He, J. B. (2014): Selection and validation of suitable reference genes in skin tissue of Liaoning cashmere goat during hair follicle cycle. Livestock Science. 1. 161: 28-35.

Beekman, L.-Tohver, T.-Dardari, R.-Léguillette, R. (2011): Evaluation of suitable reference genes for gene expression studies in bronchoalveolar lavage cells from horses with inflammatory airway disease. BMC Molecular Biology. 1. 12: 5.

Bionaz, M.-Loor, J. J. (2007): Identification of reference genes for quantitative real-time PCR in the bovine mammary gland during the lactation cycle. Physiological Genomics. 3. 29: 312-319.

Bogaert, L.-Van Poucke, M.-De Baere, C.-Peelman, L.-Gasthuys, F.-Martens, A. (2006): Selection of a set of reliable reference genes for quantitative real-time PCR in normal equine skin and in equine sarcoids. BMC Biotechnology. 6: 24-24.

Bonnet, M.-Bernard, L.-Bes, S.-Leroux, C. (2013): Selection of reference genes for quantitative real-time PCR normalisation in adipose tissue, muscle, liver and mammary gland from ruminants. Animal. 08. 7: 1344-1353.

Borowska, D.-Rothwell, L.-Bailey, R.-Watson, K.-Kaiser, P. (2016): Identification of stable reference genes for quantitative PCR in cells derived from chicken lymphoid organs. Veterinary Immunology and Immunopathology. 170: 20-24.

Bougarn, S.-Cunha, P.-Gilbert, F.-Meurens, F.-Rainard, P. (2011): Validation of candidate reference genes for normalization of quantitative PCR in bovine mammary epithelial cells responding to inflammatory stimuli. Journal of Dairy Science. 5. 94: 2425-2430.
Bruynsteen, L.-Erkens, T.-Peelman, L. J.-Ducatelle, R.-Janssens, G. P.-Harris, P. A.-Hesta, M. (2013): Expression of inflammationrelated genes is associated with adipose tissue location in horses. BMC Veterinary Research. 1. 9: 240.

Brym, P.-Ruść, A.-Kamiński, S. (2013): Evaluation of reference genes for qRT-PCR gene expression studies in whole blood samples from healthy and leukemia-virus infected cattle. Veterinary Immunology and Immunopathology. 3. 153: 302-307.

Budhia, S.-Haring, L. F.-McConnell, I.-Blacklaws, B. A. (2006): Quantitation of ovine cytokine mRNA by real-time RT-PCR. Journal of Immunological Methods. 1. 309: 160-172.

Bustin, S. A.-Benes, V.-Garson, J. A.--Hellemans, J.-Huggett, J.Kubista, M.-Mueller, R.-Nolan, T.-Pfaffl, M. W.-Shipley, G. L.-Vandesompele, J.-Wittwer, C. T. (2009): The MIQE guidelines: minimum information for publication of quantitative real-time PCR experiments. Clinical Chemistry. 55: 611-622.

Cappelli, K.-Felicetti, M.-Capomaccio, S.-Spinsanti, G.-Silvestrelli, M.-Supplizi, A.V. (2008): Exercise induced stress in horses: selection of the most stable reference genes for quantitative RT-PCR normalization. BMC Molecular Biology. 1. 9: 49.

Chapman, J. R.-Waldenström, J. (2015): With reference to reference genes: A systematic review of endogenous controls in gene expression studies. PloS One. 10: e0141853.

Chen, D.-Pan, X.-Xiao, P.-Farwell, M. A.-Zhang, B. (2011): Evaluation and identification of reliable reference genes for pharmacogenomics, toxicogenomics, and small RNA expression analysis. Journal of Cellular Physiology. 226: 2469-2477.

Chervoneva, I.-Li, Y.-Schulz, S.-Croker, S.-Wilson, C.-Waldman, S. A.-Hyslop, T. (2010): Selection of optimal reference genes for normalization in quantitative RT-PCR. BMC Bioinformatics. 11: 1 .

Chooi, W. H.-Zhou, R.-Yeo, S. S.-Zhang, F.-Wang, D. A. (2013): Determination and validation of reference gene stability for qPCR analysis in polysaccharide hydrogel-based 3D chondrocytes and mesenchymal stem cell cultural models. Molecular Biotechnology. 2. 54: 623-633.

Cieslak, J.-Mackowski, M.-Czyzak-Runowska, G.-Wojtowski, J.Puppel, K.-Kuczynska, B.-Pawlak, P. (2015): Screening for the most suitable reference genes for gene expression studies in equine milk somatic cells. PlosOne. 10. 10: 1-11.

Cinar, M. U.-Islam, M. A.-Uddin, M. J.-Tholen, E.-Tesfaye, D.Looft, C.-Schellander, K. (2012): Evaluation of suitable reference genes for gene expression studies in porcine alveolar macrophages in response to LPS and LTA. BMC Research Notes. 1. 5: 107-107.

De Boever, S.-Vangestel, C.-De Backer, P.-Croubels, S.-Sys, S. (2008): Identification and validation of housekeeping genes as internal control for gene expression in an intravenous LPS inflammation model in chickens. Veterinary Immunology and Immunopathology. 122: 312-317. 
De Ketelaere, A.-Goossens, K.-Peelman, L.-Burvenich, C. (2006): Validation of Internal Control Genes for Gene Expression Analysis in Bovine Polymorphonuclear Leukocytes. Journal of Dairy Science. 10. 89: 4066-4069.

Emam, M.-Thompson-Crispi, K.-Mallard, B. (2015): The effect of immunological status, in-vitro treatment and culture time on expression of eleven candidate reference genes in bovine blood mononuclear cells. BMC Immunology. 1. 16: 33-33.

Erkens, T.-Van Poucke, M.-Vandesompele, J.-Goossens, K.-Van Zeveren, A.-Peelman, L.J. (2006): Development of a new set of reference genes for normalization of real-time RT-PCR data of porcine backfat and longissimus dorsi muscle, and evaluation with PPARGC1A. BMC Biotechnology. 6: 41-41.

Facci, M. R.-Auray, G.--Meurens, F.-Buchanan, R.-van Kessel, J.Gerdts, V. (2011): Stability of expression of reference genes in porcine peripheral blood mononuclear and dendritic cells. Veterinary Immunology and Immunopathology. 1-2. 141: 11-15.

Fan, W.-Wang, H.-Zhang, Y.-Zhang, A.-Fan, W.-Wang, H.-Zhang, Y.-Zhang, A. (2012): Evaluation of the suitability of five housekeeping genes as internal control for quantitative real-time RT-PCR assays in chickens acutely infected with IBV M41 strain. Journal of Animal and Veterinary Advances. 11: 3064-3067.

Feng, X.-Xiong, Y.-Qian, H.-Lei, M.-Xu, D.-Ren, Z. (2010): Selection of reference genes for gene expression studies in porcine skeletal muscle using SYBR green qPCR. Journal of Biotechnology. 3. 150: 288-293.

Finot, L.-Marnet, P. G.-Dessauge, F. (2011): Reference gene selection for quantitative real-time PCR normalization: Application in the caprine mammary gland. Small Ruminant Research. 1. 95: 20-26.

Fredericksen, F.-Delgado, F.-Cabrera, C.-Yáñez, A.-Gonzalo, C.Villalba, M.-Olavarría, V. H. (2015): The effects of reference genes in qRT-PCR assays for determining the immune response of bovine cells (MDBK) infected with the Bovine Viral Diarrhea Virus 1 (BVDV-1). Gene. 1. 569: 95-103.

Frota, I. M.-Leitão, C. C.-Costa, J. J.-Brito, I. R.-van den Hurk, R.-Silva, J. R. (2011): Stability of housekeeping genes and expression of locally produced growth factors and hormone receptors in goat preantral follicles. Zygote. 1. 19: 71-83.

Garcia-Crespo, D.-Juste, R. A.-Hurtado, A. (2005): Selection of ovine housekeeping genes for normalisation by real-time RT-PCR; analysis of PrP gene expression and genetic susceptibility to scrapie. BMC Veterinary Research. 1. 1: 3.

Goossens, K.-Van Poucke, M.-Van Soom, A.-Vandesompele, J.Van Zeveren, A.-Peelman, L. J. (2005): Selection of reference genes for quantitative real-time PCR in bovine preimplantation embryos. BMC Developmental Biology. 1. 5: 1.

Gu, Y. R.-Li, M. Z.-Zhang, K.-Chen, L.-Jiang, A. A.-Wang, J. Y.Li, X. W. (2011): Evaluation of endogenous control genes for gene expression studies across multiple tissues and in the specific sets of fat- and muscle-type samples of the pig. Journal of Animal Breeding and Genetics. 4. 128: 319-325.

Hjertner, B.-Olofsson, K. M.-Lindberg, R.-Fuxler, L.-Fossum, C. (2013): Expression of reference genes and T helper 17 associated cytokine genes in the equine intestinal tract. Veterinary Journal. 3. 197: 817-823.

Hosseini, A.-Sauerwein, H.-Mielenz, M. (2009): Putative reference genes for gene expression studies in propionate and betahydroxybutyrate treated bovine adipose tissue explants. Journal of Animal Physiology and Animal Nutrition. 5. 94: e178-e184.

Huang, Y.-Chen, Y.-Sun, H.-Lan, D. (2016): Stability of Reference Gene Expression After Porcine Sapelovirus Infection in Porcine Intestinal Epithelial Cells. Viral Immunology. 6. 29: 343-349.
Janovick-Guretzky, N.-Dann, H. M.-Carlson, D. B.-Murphy, M. R.-Loor, J. J.-Drackley, J. K. (2007): Housekeeping Gene Expression in Bovine Liver is Affected by Physiological State, Feed Intake, and Dietary Treatment. Journal of Dairy Science. 5. 90: 2246-2252.

Jarczak, J.-Kaba, J.-Bagnicka, E. (2014): The validation of housekeeping genes as a reference in quantitative Real Time PCR analysis. Application in the milk somatic cells and frozen whole blood of goats infected with caprine arthritis encephalitis virus. Gene. 2. 549: 280-285.

Jiang, X.-Xue, Y.-Zhou, H.-Li, S.-Zhang, Z.-Hou, R.-Ding, Y.$\mathrm{Hu}$, K. (2015): Evaluation of reference gene suitability for quantitative expression analysis by quantitative polymerase chain reaction in the mandibular condyle of sheep. Molecular Medicine Reports. 4. 12: 5633-5640.

Kadegowda, A. K. G.-Bionaz, M.-Thering, B.-Piperova, L. S.Erdman, R. A.-Loor, J. J. (2009): Identification of internal control genes for quantitative polymerase chain reaction in mammary tissue of lactating cows receiving lipid supplements. Journal of Dairy Science. 5. 92: 2007-2019.

Kayis, S. A.-Atli, M. O.-Kurar, E.-Bozkaya, F.-Semacan, A.-Aslan, S.-Guzeloglu, A. (2011): Rating of putative housekeeping genes for quantitative gene expression analysis in cyclic and early pregnant equine endometrium. Animal Reproduction Science. 1-4. 125: 124-132.

Khan, M. I. U. R.-Dias, F. C. F.-Dufort, I.-Misra, V.-Sirard, M. A.Singh, J. (2014): Stable reference genes in granulosa cells of bovine dominant follicles during follicular growth, FSH stimulation and maternal aging. Reproduction, Fertility and Development. 6. 28: 795-805.

Klein, C.-Rutllant, J.-Troedsson, M. H. T. (2011): Expression stability of putative reference genes in equine endometrial, testicular, and conceptus tissues. BMC Research Notes. 1. 4: 120-120.

Kozera, B.-Rapacz, M. (2013): Reference genes in real-time PCR. Journal of Applied Genetics. 54: 391-406.

Kuchipudi, S. V.-Tellabati, M.-Nelli, R. K.-White, G. A.-Perez, B. B.-Sebastian, S.-Slomka, M. J.-Brookes, S. M.-Brown, I. H.Dunham, S. P. (2012): $18 S$ rRNA is a reliable normalisation gene for real time PCR based on influenza virus infected cells. Virology Journal. 9: 1.

Kuijk, E. W.-du Puy, L.-van Tol, H. T. A.-Haagsman, H. P.-Colenbrander, B.-Roelen, B. A. J. (2007): Validation of reference genes for quantitative RT-PCR studies in porcine oocytes and preimplantation embryos. BMC Developmental Biology. 1. 7: 58-58.

Lecchi, C.-Dilda, F.-Sartorelli, P.-Ceciliani, F. (2012): Widespread expression of SAA and Hp RNA in bovine tissues after evaluation of suitable reference genes. Veterinary Immunology and Immunopathology. 1. 145: 556-562.

Lee, W. J.-Jeon, R. H.-Jang, S. J.-Park, J. S.-Lee, S. C.-Baregundi Subbarao, R.-Lee, S. L.-Park, B. W.-King, W. A.-Rho, G. J. (2015): Selection of Reference Genes for Quantitative Gene Expression in Porcine Mesenchymal Stem Cells Derived from Various Sources along with Differentiation into Multilineages. Stem Cells International. 2015: 235192.

Li, Q.-Domig, K. J.-Ettle, T.-Windisch, W.-Mair, C.-Schedle, K. (2011): Evaluation of potential reference genes for relative quantification by RT- qPCR in different porcine tissues derived from feeding studies. International Journal of Molecular Sciences. 3. 12: 1727-1734.

Lisowski, P.-Pierzchała, M.-Gościk, J.-Pareek, C. S.-Zwierzchowski, L. (2008): Evaluation of reference genes for studies of gene expression in the bovine liver, kidney, pituitary, and thyroid. Journal of Applied Genetics. 4. 49: 367-372. 
Liu, Y.-Zhang, Y.-Jiang, Q.-Rao, M.-Sheng, Z.-Zhang, Y.-Du, W.Hao, H.-Zhao, X.-Xu, Z.-Liu, J.-Zhu, H. (2015): Identification of Valid Housekeeping Genes for Real-Time Quantitative PCR Analysis of Collapsed Lung Tissues of Neonatal Somatic Cell Nuclear Transfer-Derived Cattle. Cellular Reprogramming. 5. 17: $360-367$.

Llobat, L.-Marco-Jiménez, F.-Peñaranda, D.-Saenz-de-Juano, M.Vicente, J. (2011): Effect of Embryonic Genotype on Reference Gene Selection for RT-qPCR Normalization. Reproduction in Domestic Animals. 4. 47: 629-634.

Looijen, M. G.-New, D. J.-Fischer, C. D.-Dardari, R.-Irwin, K. M.Berezowski, C. J.-Bond, S. L.-Léguillette, R. (2016): Expression of $\mathrm{T}$ helper cell-associated inflammatory mediator mRNAs in cells of bronchoalveolar lavage fluid samples and oxygen concentration in arterial blood samples from healthy horses exposed to hyperbaric oxygen. American Journal of Veterinary Research. 10. 77: 1148-1156.

Luchsinger, C.-Arias, M. E.-Vargas, T.-Paredes, M.-Sánchez, R.Felmer, R. (2014): Stability of reference genes for normalization of reverse transcription quantitative real-time PCR (RT-qPCR) data in bovine blastocysts produced by IVF, ICSI and SCNT. Zygote. 4. 22: 505-512.

Lyahyai, J.-Serrano, C.-Ranera, B.-Badiola, J.-Zaragoza, P.Martin-Burriel, I. (2009): Effect of scrapie on the stability of housekeeping genes. Animal Biotechnology. 1. 21: 1-13.

Ma, H.-Yang, Q.-Li, D.-Liu, J. (2015): Validation of suitable reference genes for quantitative polymerase chain reaction analysis in rabbit bone marrow mesenchymal stem cell differentiation. Molecular Medicine Reports. 2. 12: 2961-2968.

Macabelli, C. H.-Ferreira, R. M.-Gimenes, L. U.-de Carvalho, Nelcio Antonio Tonizza-Soares, J. G.-Ayres, H.-Ferraz, M. L.Watanabe, Y. F.-Watanabe, O. Y.-Sangalli, J. R. (2014): Reference gene selection for gene expression analysis of oocytes collected from dairy cattle and buffaloes during winter and summer. PloSOne. 3. 9: e93287.

Mahakapuge, T.-Scheerlinck, J.-Rojas, C. A.-Every, A.-Hagen, J. (2016): Assessment of reference genes for reliable analysis of gene transcription by RT-qPCR in ovine leukocytes. Veterinary Immunology and Immunopathology. 171: 1-6.

Mamo, S.-Gal, A. B.-Polgar, Z.-Dinnyes, A. (2008): Expression profiles of the pluripotency marker gene POU5F1 and validation of reference genes in rabbit oocytes and preimplantation stage embryos. BMC Molecular Biology. 1. 9: 67.

Manjarin, R.-Trottier, N. L.-Weber, P. S.-Liesman, J. S.-Taylor, N. P.-Steibel, J. P. (2011): A simple analytical and experimental procedure for selection of reference genes for reversetranscription quantitative PCR normalization data. Journal of Dairy Science. 10. 94: 4950-4961.

Manjunath, S.-Mishra, B.-Mishra, B. P.-Saxena, S.-Mondal, P.Sahu, A. R.-Sahoo, A. P.-Tiwari, A. K.-Gandham, R. K. (2015): Identification of suitable reference gene in goat peripheral blood mononuclear cells (PBMCs) infected with peste des petits ruminants virus (PPRV). Livestock Science. 181: 150-155.

Martínez-Giner, M.-Noguera, J. L.-Balcells, I.-FernándezRodríguez, A.-Pena, R. N. (2013): Selection of internal control genes for real-time quantitative PCR in ovary and uterus of sows across pregnancy. PloSOne. 6. 8: e66023.

Martino, A.-Cabiati, M.-Campan, M.-Prescimone, T.-Minocci, D.Caselli, C.-Rossi, A. M.-Giannessi, D.-Del Ry, S. (2011): Selection of reference genes for normalization of real-time PCR data in minipig heart failure model and evaluation of TNF- $\alpha$ mRNA expression. Journal of Biotechnology. 3. 153: 92-99.
McBryan, J.-Hamill, R. M.-Davey, G.-Lawlor, P.-Mullen, A. M. (2010): Identification of suitable reference genes for gene expression analysis of pork meat quality and analysis of candidate genes associated with the trait drip loss. Meat Science. 2. 86: 436-439.

McCulloch, R. S.-Ashwell, M. S.-T O’Nan, A.-Mente, P. L. (2012): Identification of stable normalization genes for quantitative real-time PCR in porcine articular cartilage. Journal of Animal Science and Biotechnology. 1. 3: 36.

Mihi, B.-Rinaldi, M.-Geldhof, P. (2011): Effect of an Ostertagia ostertagi infection on the transcriptional stability of housekeeping genes in the bovine abomasum. Veterinary Parasitology. 2-4. 181: 354-359.

Modesto, P.-Peletto, S.-Pisoni, G.-Cremonesi, P.-Castiglioni, B.Colussi, S.-Caramelli, M.-Bronzo, V.-Moroni, P.-Acutis, P. L. (2013): Evaluation of internal reference genes for quantitative expression analysis by real-time reverse transcription-PCR in somatic cells from goat milk. Journal of Dairy Science. 12. 96: 7932-7944.

Monaco, E.-Bionaz, M.-de Lima, A.--Hurley, W. L.-Loor, J. J.Wheeler, M. B. (2010): Selection and reliability of internal reference genes for quantitative PCR verification of transcriptomics during the differentiation process of porcine adult mesenchymal stem cells. Stem Cell Research \& Therapy. 1. 1: 7-7.

Muráni, E.-Murániová, M.-Ponsuksili, S.-Schellander, K.-Wimmers, K. (2007): Identification of genes differentially expressed during prenatal development of skeletal muscle in two pig breeds differing in muscularity. BMC Developmental Biology. 1. 7: 109 .

Nachar, W.-Busseuil, D.-Shi, Y.-Mihalache-Avram, T.-Mecteau, M.-Rhéaume, E.-Tardif, J. (2014): Optimisation of reference genes for gene-expression analysis in a rabbit model of left ventricular diastolic dysfunction. PloSOne. 2. 9: e89331.

Najafpanah, M. J.-Sadeghi, M.-Bakhtiarizadeh, M. R. (2013): Reference genes selection for quantitative real-time PCR using RankAggreg method in different tissues of Capra hircus. PlosOne. 12. 8: 1-10.

Nascimento, C. S.-Barbosa, L. T.-Brito, C.-Fernandes, R. P.-Mann, R. S.-Pinto, A. P. G.-Oliveira, H. C.-Dodson, M. V.-Guimarães, S. E.-Duarte, M. S. (2015): Identification of Suitable Reference Genes for Real Time Quantitative Polymerase Chain Reaction Assays on Pectoralis major Muscle in Chicken (Gallus gallus). PloS One. 10: e0127935.

Nesvadbová, M.-Knoll, A. (2011): Evaluation of reference genes for gene expression studies in pig muscle tissue by real-time PCR. Czech Journal of Animal Science. 56. 56: 213-216.

Nygard, A.-Jørgensen, C. B.-Cirera, S.-Fredholm, M. (2007): Selection of reference genes for gene expression studies in pig tissues using SYBR green qPCR. BMC Molecular Biology. 1. 8: 67.

O'Connor, T.-Wilmut, I.-Taylor, J. (2013): Quantitative Evaluation of Reference Genes for Real-Time PCR During In Vitro Maturation of Ovine Oocytes. Reproduction in Domestic Animals. 3. 48: 477-483.

Ontsouka, E. C.-Reist, M.-Graber, H.-Blum, J. W.-Steiner, A.Hirsbrunner, G. (2004): Expression of messenger RNA coding for 5-HT receptor, alpha and beta adrenoreceptor (subtypes) during oestrus and dioestrus in the bovine uterus. Journal of Veterinary Medicine Series A: Physiology Pathology Clinical Medicine. 9-10. 51: 385-393. 
Ostrowska, M.-Żelazowska, B.-Słoniewski, K.-Kowalski, Z.Zwierzchowski, L. (2014): Selecting the best references in gene expression experiments in liver of cows receiving glucogenic supplements during the transition period. Journal of Dairy Science. 2. 97: 911-916.

Paris, D. B.-Kuijk, E. W.-Roelen, B. A.-Stout, T. A. (2011): Establishing reference genes for use in real-time quantitative PCR analysis of early equine embryos. Reproduction, Fertility and Development. 2. 23: 353-363.

Park, S.-Kwon, S. G.-Hwang, J. H.-Park, D. H.-Kim, T. W.-Kim, C. W. (2015): Selection of appropriate reference genes for RT-qPCR analysis in Berkshire, Duroc, Landrace, and Yorkshire pigs. Gene. 1. 558: 152-158.

Passmore, M.-Nataatmadja, M.-Fraser, J. F. (2009): Selection of reference genes for normalisation of real-time RT-PCR in brain-stem death injury in Ovis aries. BMC Molecular Biology. 1. 10: 72 .

Paten, A. M.-Pain, S. J.-Peterson, S. W.-Blair, H. T.-Kenyon, P. R.Dearden, P. K.-Duncan, E. J. (2014): Identification of reference genes for RT-qPCR in ovine mammary tissue during late pregnancy and lactation and in response to maternal nutritional programming. Physiological Genomics. 15. 46: 560-570.

Peletto, S.-Bertuzzi, S.-Campanella, C.-Modesto, P.-Maniaci, M. G.-Bellino, C.-Ariello, D.-Quasso, A.-Caramelli, M.-Acutis, P. L. (2011): Evaluation of internal reference genes for quantitative expression analysis by real-time PCR in ovine whole blood. International Journal of Molecular Sciences. 11. 12: 7732-7747.

Peng, X.-Zhao, R.-Song, W.-Chu, H.-Li, M.-Song, S.-Li, G.Liang, D. (2012): Selection of suitable reference genes for normalization of quantitative real-time PCR in cartilage tissue injury and repair in rabbits. International Journal of Molecular Sciences. 11. 13: 14344-14355.

Pereira-Fantini, P.-Rajapaksa, A. E.-Oakley, R.-Tingay, D. G. (2016): Selection of reference genes for gene expression studies related to lung injury in a preterm lamb model. Scientific Reports. 6: 26476-26476.

Pérez, R.-Tupac-Yupanqui, I.-Dunner, S. (2008): Evaluation of suitable reference genes for gene expression studies in bovine muscular tissue. BMC Molecular Biology. 1. 9: 1.

Pfaffl, M. W. (2001): A new mathematical model for relative quantification in real-time RT-PCR. Nucleic Acids Research. 29: e45.

Pfaffl, M. W.-Tichopad, A.-Prgomet, C.-Neuvians, T. P. (2004): Determination of stable housekeeping genes, differentially regulated target genes and sample integrity: BestKeeperExcel-based tool using pair-wise correlations. Biotechnology Letters. 26: 509-515.

Pierzchala, M.-Pareek, C. S.-Urbanski, P.-Goluch, D.-Kamyczek, M.-Rozycki, M.-Kuryl, J. (2011): Selection of reference genes for gene expression studies in porcine hepatic tissue using quantitative real-time polymerase chain reaction. Animal Science Papers and Reports. 1. 29: 53-63.

Piórkowska, K.-Oczkowicz, M.-Różycki, M.-Ropka-Molik, K.Piestrzyńska-Kajtoch, A. (2011): Novel porcine housekeeping genes for real-time RT-PCR experiments normalization in adipose tissue: assessment of leptin mRNA quantity in different pig breeds. Meat Science. 3. 87: 191-195.

Puech, C.-Dedieu, L.-Chantal, I.-Rodrigues, V. (2015): Design and evaluation of a unique SYBR Green real-time RT-PCR assay for quantification of five major cytokines in cattle, sheep and goats. BMC Veterinary Research. 1. 11: 65.
Rekawiecki, R.-Kowalik, M. K.-Kotwica, J. (2013): Validation of housekeeping genes for studying differential gene expression in the bovine myometrium. Acta Veterinaria Hungarica. 4. 61: 505-516.

Rekawiecki, R.-Rutkowska, J.-Kotwica, J. (2012): Identification of optimal housekeeping genes for examination of gene expression in bovine corpus luteum. Reproductive Biology. 4. 12: 362-367.

Robinson, T.-Sutherland, I.-Sutherland, J. (2007): Validation of candidate bovine reference genes for use with real-time PCR. Veterinary Immunology and Immunopathology. 1. 115: 160-165.

Ropka-Molik, K.-Oczkowicz, M.-Mucha, A.-Piórkowska, K.Piestrzyńska-Kajtoch, A. (2012): Variability of mRNA abundance of leukemia inhibitory factor gene (LIF) in porcine ovary, oviduct and uterus tissues. Molecular Biology Reports. 8. 39: 7965-7972.

Ross, P. J.-Wang, K.-Kocabas, A.-Cibelli, J. B. (2010): Housekeeping gene transcript abundance in bovine fertilized and cloned embryos. Cellular Reprogramming. 6. 12: 709-717.

Saremi, B.-Sauerwein, H.-Dänicke, S.-Mielenz, M. (2012): Identification of reference genes for gene expression studies in different bovine tissues focusing on different fat depots. Journal of Dairy Science. 6. 95: 3131-3138.

Schoen, K.-Plendl, J.-Gabler, C.-Kaessmeyer, S. (2014): Identification of Stably Expressed Reference Genes for RT-qPCR Data Normalization in Defined Localizations of Cyclic Bovine Ovaries. Anatomia, Histologia, Embryologia. 3. 44: 200-211.

Serrano, M.-Moreno-Sánchez, N.-González, C.-Marcos-Carcavilla, A.-Van Poucke, M.-Calvo, J. H.-Salces, J.-Cubero, J.-Carabaño, M. J. (2011): Use of Maximum Likelihood-Mixed Models to select stable reference genes: a case of heat stress response in sheep. BMC Molecular Biology. 1. 12: 36.

Silver, N.-Best, S.-Jiang, J.-Thein, S. L. (2006): Selection of housekeeping genes for gene expression studies in human reticulocytes using real-time PCR. BMC Molecular Biology. 7: 1.

Skovgaard, K.-Mortensen, S.-Poulsen, K. T.-Angen, Ø.-Heegaard, P. M. (2007): Validation of putative reference genes for qRT-PCR normalization in tissues and blood from pigs infected with Actinobacillus pleuropneumoniae. Veterinary Immunology and Immunopathology. 1. 118: 140-146.

Smits, K.-Goossens, K.-Van Soom, A.-Govaere, J.-Hoogewijs, M.Vanhaesebrouck, E.-Galli, C.-Colleoni, S.-Vandesompele, J.Peelman, L. (2009): Selection of reference genes for quantitative real-time PCR in equine in vivo and fresh and frozen-thawed in vitro blastocysts. BMC Research Notes. 1. 2: 246.

Spalenza, V.-Girolami, F.-Bevilacqua, C.-Riondato, F.-Rasero, R.Nebbia, C.-Sacchi, P.-Martin, P. (2011): Identification of internal control genes for quantitative expression analysis by real-time PCR in bovine peripheral lymphocytes. Veterinary Journal. 3. 189: 278-283.

Svobodová, K.-Bílek, K.-Knoll, A. (2008): Verification of reference genes for relative quantification of gene expression by real-time reverse transcription PCR in the pig. Journal of Applied Genetics. 3. 49: 263-265.

Thorrez, L.-Van Deun, K.-Tranchevent, L.-Van Lommel, L.-Engelen, K.-Marchal, K.-Moreau, Y.-Van Mechelen, I.-Schuit, F. (2008): Using ribosomal protein genes as reference: a tale of caution. PloS One. 3: e1854.

Tramontana, S.-Bionaz, M.-Sharma, A.-Graugnard, D.-Cutler, E.Ajmone-Marsan, P.-Hurley, W.-Loor, J. (2008): Internal controls for quantitative polymerase chain reaction of swine mammary glands during pregnancy and lactation. Journal of Dairy Science. 8. 91: 3057-3066. 
Uddin, M. J.-Cinar, M. U.-Tesfaye, D.-Looft, C.-Tholen, E.-Schellander, K. (2011): Age-related changes in relative expression stability of commonly used housekeeping genes in selected porcine tissues. BMC Research Notes. 1. 4: 441.

Vandesompele, J.-De Preter, K.-Pattyn, F.-Poppe, B.-Van Roy, N.De Paepe, A.-Speleman, F. (2002): Accurate normalization of real-time quantitative RT-PCR data by geometric averaging of multiple internal control genes. Genome Biology. 3: 1 .

Verbeke, J.-Van Poucke, M.-Peelman, L.-De Vliegher, S. (2015): Differential expression of $C X C R 1$ and commonly used reference genes in bovine milk somatic cells following experimental intramammary challenge. BMC Genetics. 1. 16: 40.

Vorachek, W. R.-Bobe, G.-Hall, J. A. (2013): Reference gene selection for quantitative PCR studies in sheep neutrophils. International Journal of Molecular Sciences. 6. 14: 11484-11495.

Walker, C. G.-Meier, S.-Mitchell, M. D.--Roche, J. R.--Littlejohn, M. (2009): Evaluation of real-time PCR endogenous control genes for analysis of gene expression in bovine endometrium. BMC Molecular Biology. 1. 10: 100.

Wang, J.-Wang, Y.-Wang, H.-Hao, X.-Wu, Y.-Guo, J. (2014): Selection of Reference Genes for Gene Expression Studies in Porcine Whole Blood and Peripheral Blood Mononuclear Cells under Polyinosinic:Polycytidylic Acid Stimulation. AsianAustralasian Journal of Animal Sciences. 4. 27: 471-478.

Wang, Y.-Zhao, Y.-Li, J.-Liu, H.--Ernst, C. W.-Liu, X.--Liu, G.-Xi, Y.-Lei, M. (2015): Evaluation of housekeeping genes for normalizing real-time quantitative PCR assays in pig skeletal muscle at multiple developmental stages. Gene. 2. 565: 235-241.

Xiang-Hong, J.-Yan-Hong, Y.-Han-Jin, X.-Li-long, A.-Ying-Mei, X.-Pei-Rong, J.-Ming, L. (2011): Selection of reference genes for gene expression studies in PBMC from Bama miniature pig under heat stress. Veterinary Immunology and Immunopathology. 1-2. 144: 160-166.

Xu, H.-Bionaz, M.-Sloboda, D. M.-Ehrlich, L.-Li, S.-Newnham, J. P.-Dudenhausen, J. W.-Henrich, W.-Plagemann, A.-Challis, J. R. (2015): The dilution effect and the importance of selecting the right internal control genes for RT-qPCR: a paradigmatic approach in fetal sheep. BMC Research Notes. 1. 8: 58.
Yang, F.-Lei, X.-Rodriguez-Palacios, A.-Tang, C.-Yue, H. (2013): Selection of reference genes for quantitative real-time PCR analysis in chicken embryo fibroblasts infected with avian leukosis virus subgroup J. BMC Research Notes. 6: 1.

Yue, H.-Lei, X.-Yang, F.-Li, M.-Tang, C. (2010): Reference gene selection for normalization of PCR analysis in chicken embryo fibroblast infected with H5N1 AIV. Virologica Sinica. 25: 425-431.

Zang, R.-Bai, J.-Xu, H.-Zhang, L.-Yang, J.-Yang, L.-Lu, J.-Wu, J. (2011): Selection of suitable reference genes for real-time quantitative PCR studies in Lanzhou fat-tailed sheep (Ovis aries). Asian Journal of Animal and Veterinary Advances. 8. 6: 789-804.

Zaros, L. G.-Coutinho, L. L.-Sider, L. H.-Medeiros, H. R. D.Neves, Maria Rosalba Moreira das-Benvenuti, C. L.-Navarro, Andrine Maria do Carmo-Vieira, L. D. S. (2010): Evaluation of reference genes for real-time PCR studies of Brazilian Somalis sheep infected by gastrointestinal nematodes. Genetics and Molecular Biology. 3. 33: 486-490.

Zhang, J.-Tang, Z.-Wang, N.-Long, L.-Li, K. (2012): Evaluating a set of reference genes for expression normalization in multiple tissues and skeletal muscle at different development stages in pigs using quantitative real-time polymerase chain reaction. DNA and Cell Biology. 1. 31: 106-113.

Zhang, Y. W.-Davis, E. G.-Bai, J. (2009): Determination of internal control for gene expression studies in equine tissues and cell culture using quantitative RT-PCR. Veterinary Immunology and Immunopathology. 1-2. 130: 114-119.

Zhang, Y.-Zhang, X. D.-Liu, X.-Li, Y. S.-Ding, J. P.-Zhang, X. R.Zhang, Y. H. (2013): Reference gene screening for analyzing gene expression across goat tissue. Asian-Australasian Journal of Animal Sciences. 12. 26: 1665-1671.

Zhao, H.-Liu, J.-Li, Y.-Yang, C.-Zhao, S.-Liu, J.-Liu, A.-Liu, G.Yin, H.-Guan, G.-Luo, J. (2016): Validation of reference genes for quantitative real-time PCR in bovine PBMCs transformed and non-transformed by Theileria annulata. Korean Journal of Parasitology. 1. 54: 39-46.

Zhu, W.-Lin, Y.-Liao, H.-Wang, Y. (2015): Selection of reference genes for gene expression studies related to intramuscular fat deposition in Capra hircus skeletal muscle. PloSOne. 3. 10: e0121280. 
